\title{
Hystometric evaluation of nickel chronic exposure effects on large instestine of adult Wistar male rats
}

\author{
Evaluación histométrica de los efectos de la exposición crónica al níquel \\ en el intestino grueso de ratas macho Wistar adultas
}

\author{
Maria Luiza Assis Rodrigues ${ }^{1}$, Sirlene Souza Rodrigues Sartori' ${ }^{2}$, Priscila Izabel Santos Totaro ${ }^{3}$, \\ Sérgio Luis Pinto da Matta ${ }^{4}$.
}

\begin{abstract}
ARTICLE DATA
1 Bacharela of Biological Sciences, Universidade Federal de Viçosa, Viçosa, Brasil, mlar2205@gmail. com.

2 Doctor in Biologia Celular e Estrutura, Universidade Federal de Viçosa, Viçosa, Brasil, sirlene.rodrigues@ufv.br

3 Doctor in Biologia Celular, Universidade Federal de Minas Gerais, Belo Horizonte, Brasil,

4 Doctor em Biologia Celular, Universidade Federal de Viçosa, Viçosa, Brasil, smatta@ufv.br
\end{abstract}

Cite: Rodrigues, M., Sartori, S., Totaro, P. \& da Matta, S. (2019). Hystometric evaluation of nickel chronic exposure effects on large instestine of adult Wistar male rats. Revista de Ciencias Agrícolas. 36(E): 21-30 doi: https://doi.org/10.22267/rcia.1936E.103

Received: June 222019.

Accepted: October 162019.

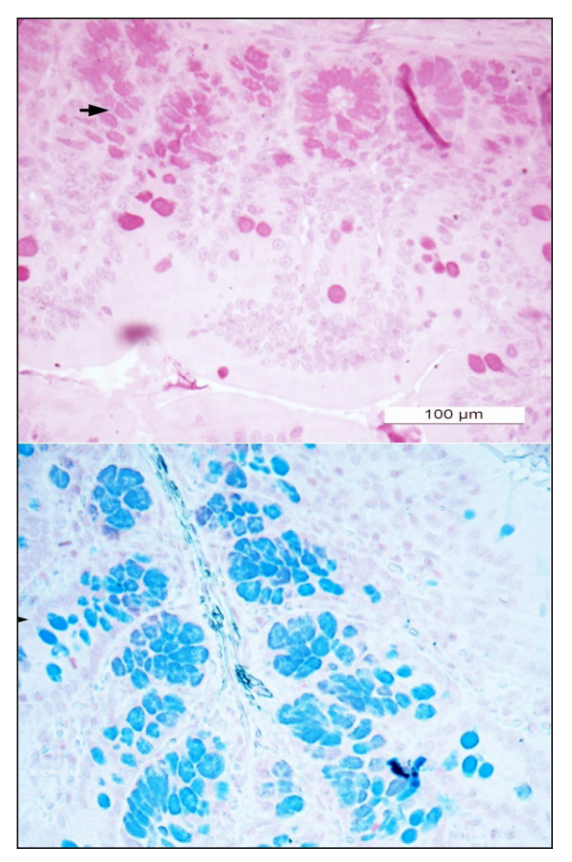

ABSTRACT

The ingestion of considerable amounts of water or food contaminated with nickel can be very toxic. The present work was conducted aiming to evaluate the effects of nickel exposures on ascending colon of adult Wistar male rats at hystometric level. We used 12 animals that were divided in a control (ingested uncontaminated water) and a nickel-contaminated (i.e., $25 \mathrm{mg}$ de nickel/L of water) groups. Nickel chloride was offered in declorinated water and the experiment had a 56 days exposure period. A portion of the ascending colon was removed of the animals and subjected to hystological labelling processes using blue toluidin (for general hystometric description), Alcian Blue (AB, for acid mucins) and periodic acid-Schiff (PAS) technique (for neutral mucins). The potential differences between groups were desgined by applying the Whitney test and $t$ test $(\mathrm{p}<0.05)$. The crypts were smaller for the nickel-contaminated group, even though these organism exhibited broader and higher crypts. Nickel-contaminated animals exhibited a smaller amount of calyceform cells with $\mathrm{AB}$ and PAS positive reactions as well as a less mucus quantities when compared with nickel-uncontaminated animals. Such reductions on the amount of calyceform cells with $\mathrm{AB}$ and PAS positive reactions may be related wiht the shallower crypts, which possibly reduced the synthesis and secretion of mucins, compromissing the functional aspects (e.g., lubrification and intestinal mucosa protection) of the nickel-contaminated large intestines. Interestingly, the wider and higher crypts and higher epithelium collumn on the nickel-contaminated animals may represent a relevant trade-off for the intestinal mucosa protection.

Keywords: nickel contamination, toxicology, hystology, morphology.

\section{RESUMEN}

La ingestión de cantidades considerables de agua o alimentos contaminados con níquel puede ser muy tóxica. El presente trabajo se realizó con el objetivo de evaluar los efectos de las exposiciones al níquel en el colon ascendente de ratas macho Wistar adultas a nivel histométrico. Utilizamos 12 animales que se dividieron en un control (agua ingerida no contaminada) y un grupo contaminado con níquel (es decir, $25 \mathrm{mg}$ de níquel / L de agua). Se ofreció cloruro de níquel en agua desclorinada y el experimento tuvo un período de exposición de 56 días. Una parte del colon ascendente se retiró de los animales y se sometió a procesos de marcaje histológico usando toluidina azul (para descripción histométrica general), azul de Alcian (AB, para mucinas ácidas) y la técnica periódica de ácido-Schiff (PAS) (para mucinas neutras). Las diferencias potenciales entre los grupos se diseñaron mediante la aplicación de la prueba 


\begin{abstract}
de Whitney y la prueba $\mathrm{t}(\mathrm{p}<0.05)$. Las criptas eran más pequeñas para el grupo contaminado con níquel, a pesar de que estos organismos exhibían criptas más amplias y más altas. Los animales contaminados con níquel exhibieron una menor cantidad de células caliceiformes con reacciones positivas AB y PAS, así como una menor cantidad de moco en comparación con los animales no contaminados con níquel. Dichas reducciones en la cantidad de células caliceiformes con reacciones positivas AB y PAS pueden estar relacionadas con las criptas menos profundas, lo que posiblemente redujo la síntesis y secreción de mucinas, comprometiendo los aspectos funcionales (p. Ej., lubricación y protección de la mucosa intestinal) del intestino grueso contaminado con níquel. Curiosamente, las criptas más anchas y más altas y la columna de epitelio más alta en los animales contaminados con níquel pueden representar una compensación relevante para la protección de la mucosa intestinal.
\end{abstract}

Palabras clave: contaminación de níquel, toxicología, histología, morfología.

\section{INTRODUCTION}

Nickel is a heavy metal naturally found in the earth's crust at about $0.009 \%$, existing as soluble and insoluble compounds in soils and waters (Bertini et al., 2001). However, the environmental nickel concentration has increased due to the anthropogenic actions (mining and industrial activities) that are involved in the production of clocks, mobil phones, coins and cardiovascular stents (Schmidt and Goebeler, 2011).

The daily nickel requirements by human beings is estimated to be between 5 and

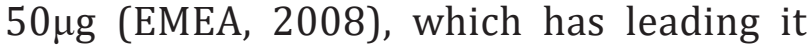
to be considered as 'potential essential' for animals, including humans, in 1970's (Nielsen and Ollerich, 1974). Interestingly, such categorization was based on some experiments using model animals but exclude the fact that no nickel-containing enzymes were found on such investigations. The potential reasons for this nickel need are still controversial but may be related to the use of nickel by the mammals' microbiota (Monachese etal., 2012). For instance, Gerbino et al. (2012) demonstrated that maximum tolerated nickel $\left(\mathrm{Ni}^{2+}\right)$ concentrations without reductions on the biomass of Lactobacillus kefir CIDC3A 8348 and JCM 5818 were of $5 \mathrm{mM}$ and $2.5 \mathrm{mM}$, respectively, which led to the conclusion that $\mathrm{Ni}^{2+}$ is a essential metal in vestigial concentrations and toxic to bacteria when in higher concentrations. Thus, when nickel is ingested in higher amounts, it becomes toxic to live organisms (Gonzalez, 2016).

The high toxicity levels of heavy metals to organisms and their easy way of enterring and accumulating along the throphic chains reinforce the relevance of investigating these metal concentrations in aquatic environments (Rocha and Azevedo, 2015). The humans daily ingest circa of $170 \mu \mathrm{g}$ of nickel through food and drink approximately $20 \mu \mathrm{g}$ of nickel. Such nickel-containing food and water ingestion have to be considered as it has been demonstrated that starving individuals absorb much more nickel on their gastrointestinal tract (Ahmad and Ashraf, 2011). The nickel absortion may vary from $12 \%$ up to $33 \%$ in starving organisms, and from 0.7 up to $6 \%$ when mixed with food (Sunderman et al., 1989; Haber et al., 2000). In investigations conducted with animals, it was demonstrated that nickel absorption by ingestion also varies with the nickel solubility, being higher for nickel soluble compounds, $9.8 \%, 11 \%$ and $34 \%$ for sulphate, chloride and nitrate ions, respectively; and lower for sulphite salts and green oxides: 0.47 and $0.01 \%$, respectively (Haber et al., 2000).

Pharmacocynetics in human beings demonstrated that nickel is absorbed through lungs, intestinal tracts and skin. In the 
respiratory tract, the nickel can be removed by mucociliar transport being delivered to gastrointestinal tract, where its absortion is not high. The absortion level is influenced by metal particules' size, chemical structure, density and eletric charge as well as by accumulation place in the organism (Clancy and Costa, 2012).

In the large intestine occurs the absorption of water and inorganic salts, leading to the formation of fecal bolus. To achieve that, the collunar cells present microvils in the apical surface and $\mathrm{Na}^{+} / \mathrm{K}^{+}$-ATPases in the basolateral membranes. The caliciforme cell are in great number and the mucus contribute to the fecal bolus compactuation, facilitating the its sliding and lubrificating the epitelial surface (Gartner and Hiatt, 2017; Lowe and Anderson, 2015). In addition to lubrification, which turns the fecal bolus progression an easier task, the colons' mucus barrier promote the chemical protection in the internal intestinal lumen against potential aggression against digestive enzymes, antigens and toxins (Hoebler et al., 2006; Gaudier et al., 2009). The mucus still present bactericidal properties, regulating the bacterial strains that are in direct contact with the epitelial surface, dificultating these organisms enter into the internal environment (Finnie et al., 1995; Corfield et al., 2000; Hoebler et al., 2006; Gaudier et al., 2009).

Thus, this research was conducted aiming to evaluate the nickel effects on the ascending colon of adult Wistar male rats at hystometric level and trying to correlate the potential alterations with the functional aspects of digestory tract.

\section{MATERIAL \& METHODS}

Animals, treatment and material collection. The animals were handled and euthanized according to the Animal Research Ethical Principles established by the Colégio Brasileiro de Experimentação Animal (COBEA, i.e., Brazilian College of Animal Experimentation - Protocol 001/11). Twelve adult Wistar rats of the same age (90 days), weighing between 276 and 302g, from the Central Biottery of the Center for Biological and Health Sciences at Universidade Federal de Viçosa (UFV, Viçosa, Minas Gerais, Brasil) were used. The animals were kept in the bioterry of the Health and Nutrition Department at UFV throughout the experimental period (56 days). The ambient temperature was $22 \pm 1^{\circ} \mathrm{C}$ and the photoperiod 12:12h (light:dark). The animals were divided into two groups (of six individuals each), individually housed in cages (18 x $34 \times 41 \mathrm{~cm})$ and fed daily (at 9:00 a.m.) with $30 \mathrm{~g}$ of pelleted commercial food (Labcil, SOCIL, São Paulo, São Paulo, Brasil). The control group received free water and whereas the nickel-treated animals received $25 \mathrm{mg}$ of nickel chloride/L of tap drinking water over the experimental period. We monitored the average daily intake of $30 \mathrm{~mL}$ of water per animal, which corresponds to a nickel consumption of $0.75 \mathrm{mg} /$ day. The animals were weighed every two weeks in order to evaluate the weight gain.

After the experimental period, the animals were anesthetized using $30 \mathrm{mg} / \mathrm{Kg}$ of the commercial combination of ketamine and xylazine (Xylazin and Cetamin, Syntec, Santana de Parnaíba, São Paulo, Brasil) and euthanized by prolongating anesthesia. After that, the animals were weighed, and a cranial portion fragment of the ascending colon was removed of each animal. The fragments were then fixed in Karnovsky solution for $24 \mathrm{~h}$ and then left in $70 \%$ alcohol. 
Hystometric evaluations of ascending colon region. The fixed ascending colon fragments were dehydrated in a growing ethyl series (alcohol 80, 90, 95\% and absolute I) and included in historesin. Semi-serial sections of $3 \mu \mathrm{m}$ thickness were obtained using a rotating microtome (model RM2245, Leica, Lincolnshire, Buffalo Grove, United States). The sections were stained with toluidine blue (in 1\% sodium borate) for tissue hystomorphological description and histometric analysis, with periodic acid-Schiff (PAS) and Alcian Blue (pH 2.5) techniques for quantifications of neutral and acidic, respectively, mucin-producing cells and the stored mucus in these cells.

Observations and photographic recordings of the sections were performed under an optical microscope with an attached digital camera (model BX53, Olympus, Miami, Florida, United States) and photomicrographs were obtained using the $10 \mathrm{x}$ objectives for the intestinal crypt's depth and width (at midpoint) and for height apical epithelium height. Objectives of 20x were used for photomicrographs used at the quantification of other caliciform cells and PAS- and AB-positive mucus-producing cells. Five fragments of each animal were randomly selected, and photomicrographs were obtained of five fragment fields per each fragment, totaling 25 photomicrographs per animal and 150 photomicrographs per animal group (control and nickel-contaminated animals).

To obtain the histometric data, the photomicrographs obtained were digitalized and analyzed using the Image J software (Media Cybernetcs, Inc, Madison, Wisconsin, United States). From the histological images, we conducted five measurements for each parameter (depth and width of intestinal crypts and height of the apical epithelium), obtaining 125 measurements/animal/ parameter. The quantification of caliciform cells and PAS- and AB-positive mucus-producing cells per $\mu \mathrm{m}^{2}$ (photographic field area) were obtained by counting all stained cells in the field.

Statiscal analyses. The normality of Kolmogorov-Smirnov and homoscedasticity of Cochran tests were conducted using the Prisma (Graphpad software, San Diego, California, United States) software. Once these assumptions were achieved, a t-test $(P<$ 0.05 ) was conducted for comparing the values obtained for nickel-unexposed (control) and nickel-treated animals. When the normality and homoscedasticity were not achieved, it was conducted such comparison using the Mann-Whitney nonparametric test $(P<0.05)$.

\section{RESULTS AND DISCUSSION}

Some researchers and toxicologists are focusing on the risk of environmental pollution by heavy metals, which are dangerous and cause effects related to animal studies, toxic effects due to oral exposure, with the possibility of slow development (Domshlak et al., 2005).

In the present study, the animals used with 25 $\mathrm{mg} / \mathrm{L}$ NiCL2 showed no significant changes $(P>0.05)$ in body weight, although there was a tendency to decrease in weight gain (Figure 1). Several studies have evaluated nickel toxicity by oral exposure at different chronic doses, and a significant reduction in body weight has been observed (Dieter et al., 1988; Obone et al., 1999; Cempel and Janicka, 2002; Gill et al, 2002). The toxic effects by chemicals in biological systems are determined by the concentration mechanism and the exposition time (Oga et al., 2008). Therefore, the dose used in this study may not have been sufficient to cause significant reduction in body weight of these animals. 


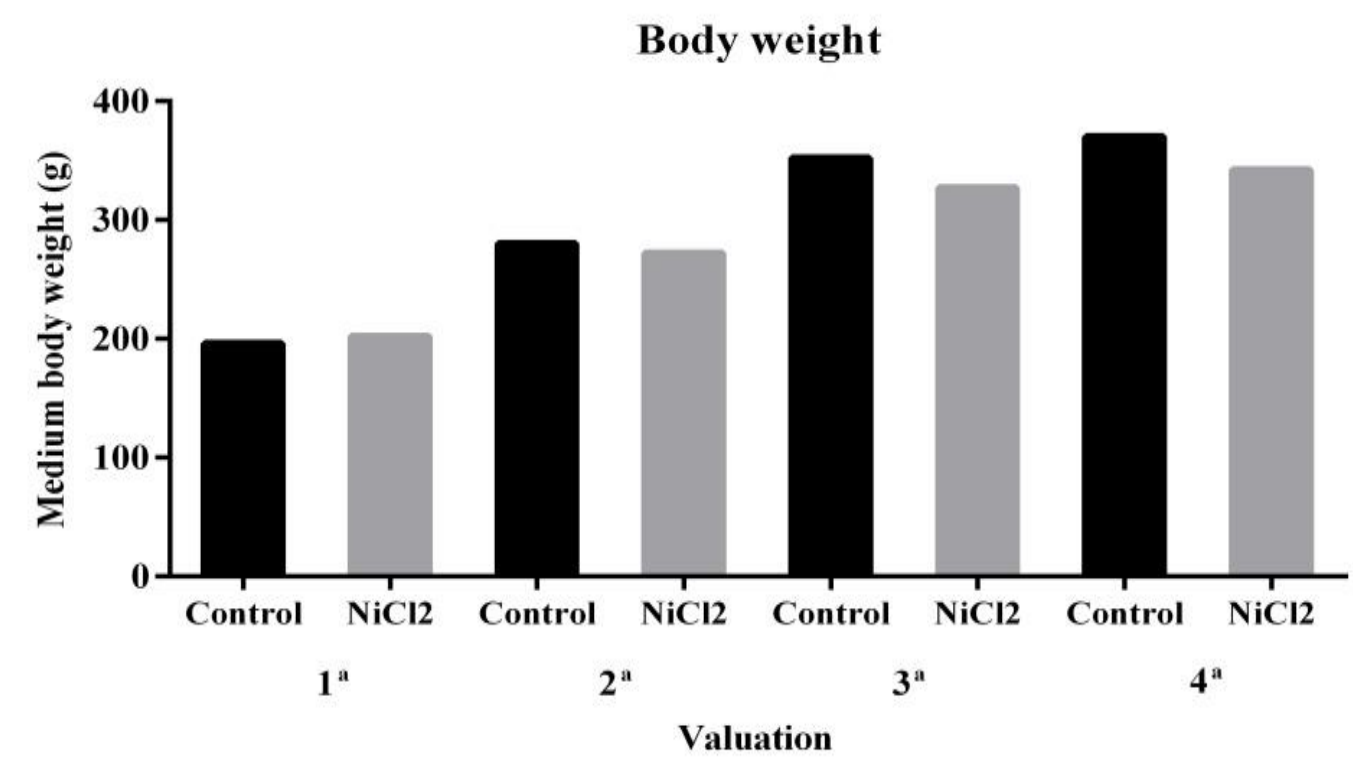

There was no statistically significant difference. Data are expressed as mean \pm standard error (SE). ${ }^{*} P<0.05$ (t- test).

Figure 1. Effect of nickel chloride exposure on body weight of adult male Wistar rats. Four weight measurements were performed at two week intervals.

However, the other hystometric evaluated parameters showed significant differences between the animal groups (Figures 2 and Figure 3). Here, it was showed a reduction in the number of caliciform cells and in the amount of PAS- (Figures 2A and B; 3C and D) and AB-positive mucus (Figure $2 \mathrm{C}$ and $\mathrm{D}$; Figures $3 \mathrm{E}$ and $\mathrm{F}$ ) in the large intestine of nickel-exposed Wistar male rats. The number of caliciform cells demonstrates the potential for mucus secretion and colonic gland activity (Glotzer et al.,1981). Changes in the composition and pattern of mucin secretion in the intestinal crypts have been observed in several inflammatory diseases that reach the colon, such as bacterial colitis, nonspecific ulcerative colitis, Crohn's disease, exclusion colitis, adenomatous polyps and colorectal cancer (Filipe 1969; Finnie et al., 1995; Keli et al., 1997;). In nonspecific colitis, the total production of acid and neutral mucins are reduced, being absent in some cases and in regions with severe inflammatory process (Filipe, 1969). Thus, a reduction in mucin secretion is seen as a detrimental effect in the intestinal protection and lubrication as well as in mucin-mediated processes such as cellcell and cell-substrate interactions, wounding and immune response modulations (Kim and Gum, 1995). 
A

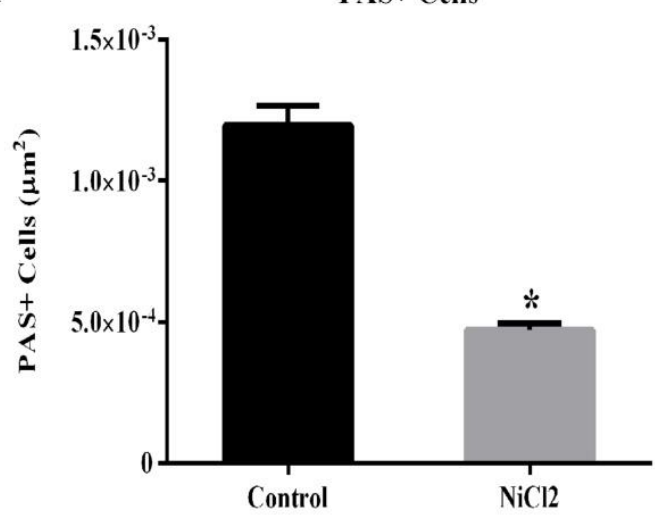

C

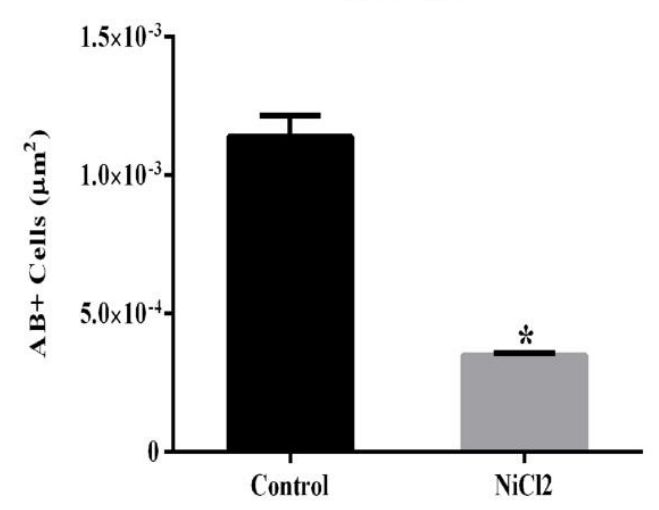

B

PAS+ Mucin Marking

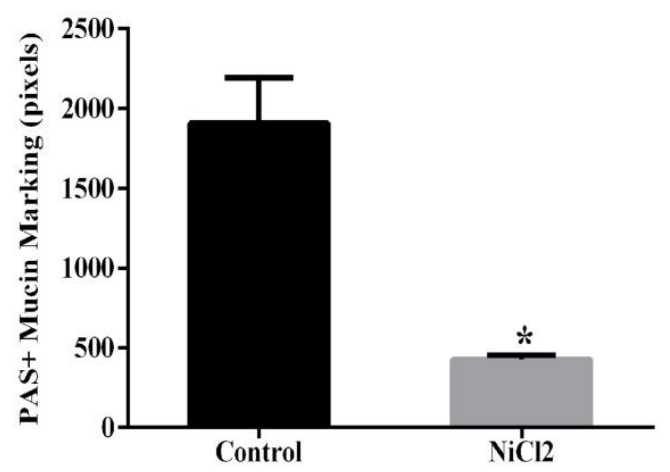

D

$\mathbf{A B}+$ mucin marking

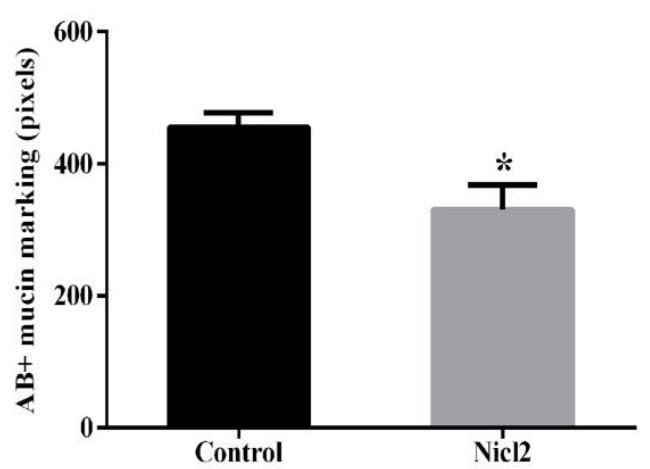

Data are expressed as mean \pm standard error (SE). ${ }^{*} P<0.05$ (t- test).

Figure 2. Effects of nickel chloride exposure on the number of caliciform cell with PAS- $(\boldsymbol{A})$ and AB- $(\boldsymbol{C})$ positive reactions ( $\boldsymbol{A}$ and $\boldsymbol{C}$, respectively) on colon of adult Wistars rats. The intensity of PAS- and AB-positive mucin marking ( $\boldsymbol{B}$ and $\boldsymbol{D}$ ) were also presented. 


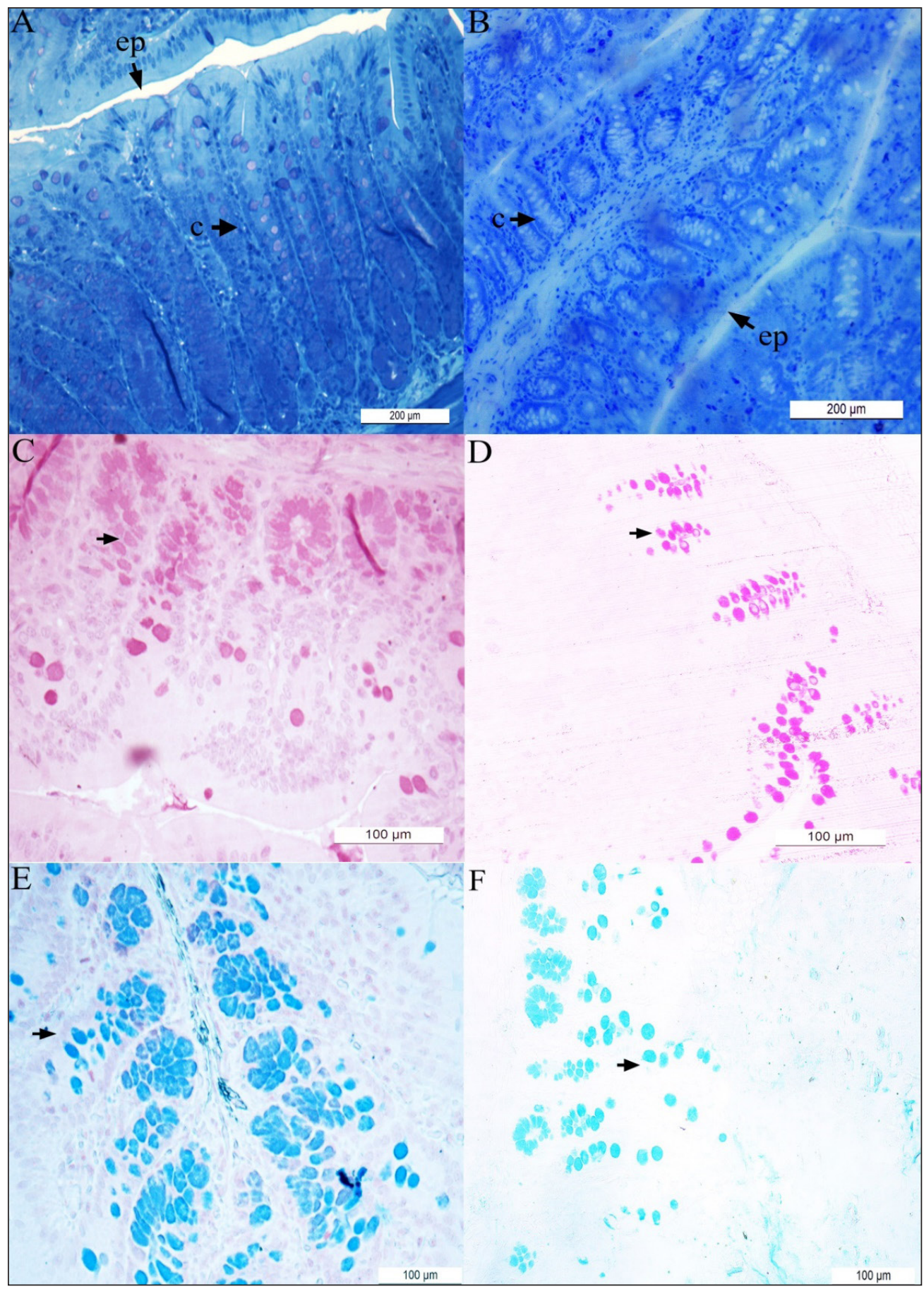

The results obtained for control (i.e., nickel-unexposed) animals are presented in panels $(\boldsymbol{A}),(\boldsymbol{C})$ and $(\boldsymbol{E})$ while the results obtained for nickel $(25 \mathrm{mg} / \mathrm{L})$-exposed animals are presented in panels $(\boldsymbol{B}),(\boldsymbol{D})$ and $(\boldsymbol{F})$. The epithelium (ep) and intestinal crypts (c) are shown in the material stained with toluidine blue $(\boldsymbol{A}-\boldsymbol{B})$. Material stained with periodic acid-Schiff (PAS) $(\boldsymbol{C}-\boldsymbol{D})$ and Alcian Blue (AB) $(\boldsymbol{E}-\boldsymbol{F})$ techniques are also shown. The arrowheads indicated the neutral $(\boldsymbol{C}-\boldsymbol{D})$ and acid $(\boldsymbol{E}-\boldsymbol{F})$ mucing-producing cells.

Figure 3. Hystological microphotographies of colon of Wistar rats. 
The decrease in crypt depth (Figures 3A and $\mathrm{B}$; Figure 4A) reflects the reduction in the number of mucus producing cells. Previous studies have shown that animals that had their fecal transit decreased, also had a decrease in the number of mucous cells, whic led to significant reduction in crypt depth (Mello et al., 2012). In the present investigation, it was also demonstrate an increase in crypt width (Figures $3 \mathrm{~A}$ and $\mathrm{B}$; Figure 4B) and epithelium height (Figure $3 \mathrm{~A}$ and B; Figure 4C) in animals exposed to nickel chloride. Such changes can be understood as a compensatory mechanism for protection of intestinal mucosa, as the mucus barrier was subjected to relevant alterations (reduction in the number of caliciform cells.
A

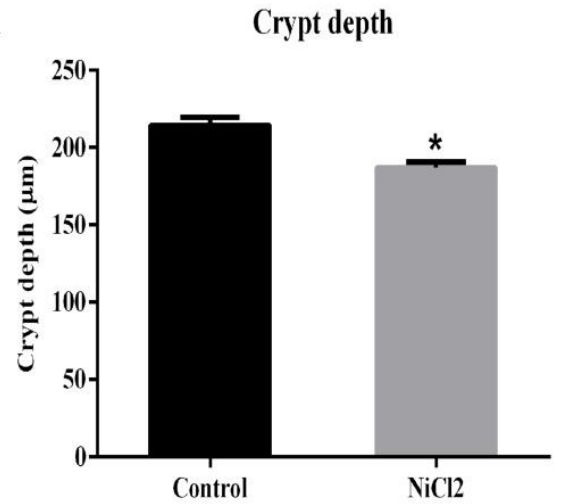

$\mathrm{C}$

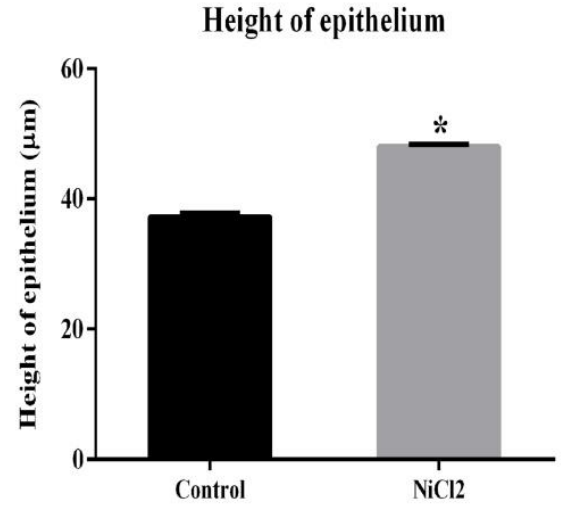

B

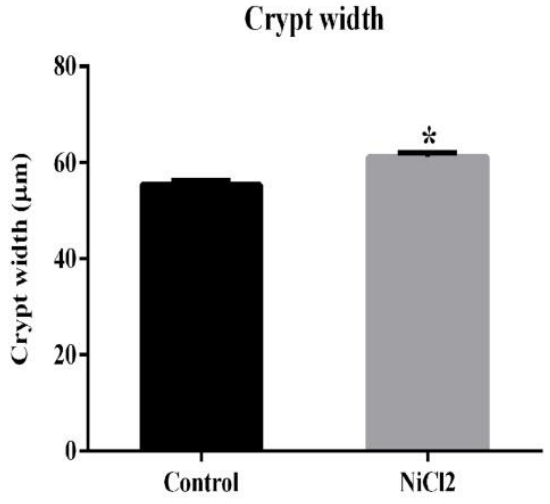

Figure 4. Effect of nickel chloride exposures on the colon of adult Wistars rats. Crypt's depth $(\boldsymbol{A})$ and width $(\boldsymbol{B}) .(\boldsymbol{C})$ Epithelium height. Data are expressed as mean \pm standard error (SE). ${ }^{*} P<0.05$ (Mann-Whitney test). 


\section{CONCLUSIONS}

The chronic exposure to nickel impacted the colong region of Wistar adult male rats. The smaller number of caliciform cells and lower PAS- and AB-positive mucus production is certainly related to reduced crypt depth in nickel-exposed animals, which may compromised the functional aspects of the large intestine (e.g., lubrication and protection of the intestinal mucosa). The larger values for crypt width and epithelium height may be a compensatory mechanism for protection of the intestinal mucosa as the mucus barrier was also altered.

Conflict of interest: The authors declare that there is no conflict of interest.

\section{BIBLIOGRAPHIC REFERENCES}

Ahmad, M. S. \& Ashraf, M. (2011). Essential roles and hazardous effects of nickel in plants. Rev. Environmental Contamination and Toxicology. 214: 125-167. doi: http://dx.doi. org/10.1007/978-1-4614-0668-6_6

Bertini, I., Sigel, A. \& Sigel, H. (2001). Handbook on Metalloproteins. 1th ed. New York: Marcel Dekker. 1182p.

Cempel, M., Janicka, K. (2002). Distribution of nickel, zinc, and copper in rat organs after oral administration of nickel (II) chloride. Biological Trace Element Research. 90 (1-3): 215-226. doi: 10.1385/BTER:90:1-3:215

Clancy, H. \& Costa, M. (2012). Nickel: A pervasive carcinogen. Future Oncology. 8 (12): 1507-1509. doi:10.2217/fon.12.154

Corfield, A.P., Myerscough, N., Longman, R., Sylvester, P., Arul, S. \& Pignatelli, M. (2000). Mucins mucosal protection in the gastrointestinal tract: new prospects for mucins in the pathology of gastrointestinal disease. Gut. 47 (4): 589-594. doi: http://dx.doi.org/10.1136/gut.47.4.589
Dieter, M. P., Jameson, C. W., Tucker, A. N. (1988). Evaluation of tissue disposition, myelopoietic, and immunologic responses in mice after long-term exposure to nickel sulfate in the drinking water. Journal of Toxicology Environmental Health. 24 (3): 356-372. doi: $10.1080 / 15287398809531167$

Domshlak, M. G., Elakov, A. L., Osipov, A. N. (2005). Genetic effects induced by nickel sulfate in germline and somatic cells of WR mice. Russian Journal of Genetics. 41(7): 728-734

EMEA - Europe, the Middle East and Africa. (2008). Guideline on the Specification Limits for Residues of Metal Catalysts ormetal Reagents, European Medicines Agency. Retrieved from https://www.ema.europa.eu/en/documents/ scientific-guideline/guideline-specificationlimits-residues-metal-catalysts-metal-reagents en.pdf.

Filipe, M. I. (1969). Value of histochemical reactions for mucosubstances in the diagnosis of certain pathological conditions of the colon and rectum. Gut. 10(7): 577-586. doi: http://dx.doi. org/10.1136/gut.10.7.577

Finnie, I.A., Dwarakanath, A.D., Taylor, B.A. \& Rhodes, J.M. (1995). Colonic mucins synthesis is increased by sodium butyrate. Gut. 36(1): 93-99. doi: http://dx.doi.org/10.1136/gut.36.1.93

Gartner, L.P. \& Hiatt, J.L. (2017). Tratado de histologia. 4th ed. Rio De Janeiro: Elsevier. 325p.

Gaudier, E., Rival, M., Buisine, M.P., Robineau, I. \& Hoebler, C. (2009). Butyrate enemas upregulate Muc genes expression but decrease adherent mucus thickness in mice colon. Physiological research. 58 (1): 111-119.

Gerbino, E., Mobili, P., Tymczyszyn, E., FraustoReyes, C., Araujo-Andrade, C. \& Gómez-Zavaglia, A. (2012). Use of Raman spectroscopy and chemometrics for the quantification of metal ions attached to Lactobacillus kefir. Journal of applied microbiology. 112 (2): 363-371. doi: 10.1111/j.1365-2672.2011.05210 
Gill, S., Kavanagh, M., Cherry, W., Bourque, C., Caldwell, D., Wang, G., Bondy, G. (2002). A rangefinding 90-day oral (gavage) toxicity study in Fischer 344 rats with nickel sulfate hexahydrate. Food. Chem. Toxicol. 111:341-355. doi: 10.1016/j. fct.2017.10.055

Glotzer, D.J., Glick, M.E. \& Goldman, H. (1981). Proctitis and colitis following diversion of fecal stream. Gastroenterology. 80 (3): 438-441.

Gonzalez, K.R. (2016). Toxicologia do Níquel. Revista intertox de toxicologia risco ambiental $e$ sociedade. 9 (2): 30-54.

Haber, L.T., Erdreicht, L., Diamond, G.L., Maier, A.M., Ratney, R.,Zhao, Q.\& Dourson, M.L. (2000). Hazard identification and dose response of inhaled nickelsoluble salts. Regul Toxicol Pharmacol. 31 (2): 210-30. doi:10.1006/rtph.2000.1377.

Hoebler, C., Gaudier, E., De Coppet, P., Rival, M. \& Cherbut, C. (2006). MUC genes are differentially expressed during onset, maintenance of inflammation in dextran sodium sulfate-treated mice. Dig Dis Sci. 51 (2): 381-389. doi: http:// dx.doi.org/10.1007/s10620-006-3142-y

Keli, E., Bouchoucha, M., Devroede, G., Carnot, F., Ohrant, T., Cugnenc, P.H. (1997) Diversion-related experimental colitis in rats. Dis Colon Rectum. 40 (2): 222-228.

Kim, Y.S. \& Gum, J.R. (1995). Diversity of mucin genes, structure, function, and expression. Gastroenterology. 109 (3): 999-1013.

Lowe, J.S. \& Anderson, P.G. (2015). Stevens \& Lowe's Human Histology. 4th ed. Philadelphia: Elsevier Mosby. 429p.

Mello, R.O., Fonte, F.P., Silva, C.M.G., Pereira, J.A., Margarido, N.F. \& Martinez, C.A.R. (2012). Avaliação do número de células caliciformes nas criptas da mucosa colônica com e sem trânsito intestinal. Revista do Colégio Brasileiro de Cirurgiões. 39 (2): 139-45. doi: 10.1590/S010069912012000200010

Monachese, M., Burton, J. P. \& Reid, G. (2012). Bioremediation and tolerance of humans to heavy metals through microbial processes: a potential role for probiotics. Appl. Environ. Microbiol. 78 (18): 6397-6404. doi: http:// dx.doi.org/10.1128/AEM.01665-12

Nielsen, F.H. \& Ollerich, D.A. (1974). Proceedings: Nickel: a new essential trace elemento. Federation proceedings. 33 (6): 1767-1772.

Obone, E., Chakrabarty, S. K., Bai, C., Malick, M. A., Lamantagne, L., Subramanian, K. S. (1999). Toxicity and bioaccumulation of nickel sulphate in Sprague-Dawley rats following 13 weeks of subchronic exposure. Journal of Toxicology and Environmental Health. 57 (6): 379-401

Oga, S., Camargo, M. M. A., Batistuzzo, J. A. O. (2008). Fundamentos de Toxicologia. 4 th ed. São Paulo: Atheneu. 677p.

Rocha, C.H.B. \& Azevedo, L.P. (2015). Assessing the presence of heavy metals in surface Waters of the São Mateus Brook Basin, Juiz de Fora (MG), Brazil. Revista Espinhaço. 4 (2): 33-44.

Schmidt, M. \& Goebeler, M. (2011). Nickel allergies: paying the toll for innate immunity. J. Mol. Med. (Berl). 89 (10): 961-970. doi: 10.1007/s00109011-0780

Sunderman, F.W., Hopfer, S.M., Sweeney, K.R., Marcus, A.H., Most, B.M. \& Creason, J. (1989). Nickel absorption and kinetics in human volunteers. Proc Soc Exp Biol Med. 191(1): 5-11. doi: 10.3181/00379727-191-42881 